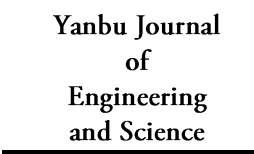

ISSN: 1658-5321
Vol. 3, October $2011(1432 \mathrm{H})$

www.yjes.org.sa

\title{
WASHABILITY STUDY OF FOUR PAKISTANI COALS BY FLOAT AND SINK TECHNIQUE-II
}

\author{
M. Arsala Khan \\ Department of Chemical Engineering Technology, \\ Yanbu Industrial College \\ P.O.Box 30436, Yanbu Al Sinaiyah, Kingdom of Saudi Arabia. \\ E-mail:mrkhan@yic.edu.sa
}

\begin{abstract}
Various Pakistani coal samples were separated into float and sink fractions using media of different specific gravities. The various float and sink fractions as well as the whole coal samples were ashed at $750{ }^{\circ} \mathrm{C}$ in a muffle furnace and the ashes were analyzed for Co, $\mathrm{Cu}, \mathrm{Ni}$, and $\mathrm{Zn}$ by atomic absorption spectrophotometer. The results showed that less enrichment of these metals occurred in the sink fraction in media of different specific gravities in case of Makarwal and Sor-Range coals. However, in case of Degari and Shahrigh coals considerable enrichment of these metals occurred in the sink fractions. The results were explained by suggesting that in case of Makarwal and Sor-Range coal samples, considerable amounts of these trace metals might occur in close association with the organic structure of coal which are difficult to be removed by the specific gravity method of coal cleaning. In case of Degari and Shahrigh coals, however considerable amounts of these metals might occur as discrete minerals matter which can be separated with ease from coal by the specific gravity method of cleaning.
\end{abstract}

Keywords: Coal, Trace metals, Float - sink separation

\section{INTRODUCTION}

Coal is a heterogeneous substance and is composed of a combustible organic matter and a noncombustible inorganic matter. The organic matter is present in the form of macerals whereas the inorganic matter is present in the form of mineral matter. Mineral matter in coal has several fold implications. Coal containing high mineral matter or ash forming material is considered low quality coal. High mineral matter in coal causes fire tubes agglomeration, fouling, sintering and corrosion during combustion for power generation. The mineral matter in coal also has adverse environmental effects.
Previous studies have shown an increase in the concentration of toxic trace elements in the biosphere resulting from coal combustion processes which have a negative impact on plant, animal and human life $[1,2]$. Beneficial effects of mineral matter have also been reported in coal liquefaction processes [3].

Extensive work has been reported in literature worldwide on the trace metals content of different coals and their mode of occurrence. A wide variation in trace metal content from the same coal mine and even in the same seam has been reported [4]. The concentration and mode of occurrence of trace elements depend on a complex set of geological interactions between the intake of trace elements during 
plant growth, enrichment during plant decay, sedimentation and diagenesis, burial and coalification and late stage mineralization [5] A generalized view of some Chinese coal, USA coals and world average has been given by Dai et al [6] Ketris and Yudovich [7] estimated world averages for trace elements in coal.

Trace elements in coal are present as main or trace components of discrete mineral phases, as adsorbed elements in inorganic materials and as part of the organic coaly structure in the form of organometallics, chelates or ionexchangable compounds [8]. The present study concerns only with the trace metals present in coal and their beneficiation in media of different specific gravities.

The organic and inorganic association of trace metals in coal is a subject of great interest from coal utilization, coal cleaning and environmental point of views .Extensive literature is available on the subject. Float sink separation of coal samples has been used as a viable tool for speciation of trace elements as whether they are organically bound in the coal matrix or present as part of discrete mineral particles. Based on float-sink analysis of coal in media of different specific gravities, Zubovic [9], listed the percentage organic affinity of some trace elements as: Ge (87), Be (82), Ga (79), Ti (78), B (77), V (76), Ni (59), Cr (55), Co (53), Y (53), Mo (40), Cu (34), Sn (27), La (3) and $\mathrm{Zn}(0)$. Gluskoter [10] separated four coal samples into a series of specific gravity fractions. The various fractions were then analyzed for trace metals. The trace metals were listed in a table in order of decreasing organic affinity. He categorizes the elements into the following four groups: Elements with greatest organic affinities (Ge, $\mathrm{Be}, \mathrm{B})$, inorganically bound elements $(\mathrm{Hg}, \mathrm{Zr}$, $\mathrm{Zn}, \mathrm{As}, \mathrm{Cd}, \mathrm{Pb}, \mathrm{Mn}$, and $\mathrm{Mo}$ ), elements closely associated with the elements having strong organic affinities $(\mathrm{P}, \mathrm{Ga}, \mathrm{Sb}, \mathrm{Ti}$, and $\mathrm{V})$ and elements closely associated with the elements having strong inorganic affinities (Co, $\mathrm{Ni}, \mathrm{Se}, \mathrm{Cr}$, and $\mathrm{Cu}$ ).

Swaine [11] suggested association of trace elements with carboxylic, phenolic, hydroxyl, mercapto, and imino groups in coal structure.

Ward [12] used float and sink fractions of six Australian coals for trace metals and found B, $\mathrm{Ni}, \mathrm{V}, \mathrm{Zr}, \mathrm{Co}$, and $\mathrm{Be}$ as having organic affinity, $\mathrm{Cu}, \mathrm{Pb}, \mathrm{Zn}, \mathrm{Mo}, \mathrm{Sr}$, and $\mathrm{Cr}$ as having inorganic affinity, whereas $\mathrm{Ge}$ as having variable affinity.

Tarazona et al [13] determined nine major and minor elements (Al, $\mathrm{Ca}, \mathrm{Fe}, \mathrm{K}, \mathrm{Mg}, \mathrm{Na}$, $\mathrm{P}, \mathrm{Si}, \mathrm{Ti})$ and thirteen trace elements $(\mathrm{Ba}, \mathrm{Cr}$, $\mathrm{Cu}, \mathrm{Mn}, \mathrm{Nb}, \mathrm{Ni}, \mathrm{Pb}, \mathrm{Rb}, \mathrm{Sr}, \mathrm{V}, \mathrm{Y}, \mathrm{Zn}$, and $\mathrm{Zr}$ ) by $\mathrm{X}$-ray fluorescence spectrometry in Austrian bituminous coals. They established the organic affinities of these trace metals using calculations based on concentration ash content relation or on the detrital mineralogy. They concluded that detrital and diagenetic minerals are the host for most of the trace elements. They argued that trace concentration in the lightest coal fractions cannot be regarded as bound to organic matter, but is part of the fine grained detrital minerals which are homogeneously distributed in the organic matrix of coal.

Preis et al [14] developed a correlation model and related it to the organic and inorganic affinities of trace elements present in Kaffioyra and Longyearbyen coals from Spitsbergen regions in Norway. They found that trace elements in Kaffioyra coals showed a high degree of inorganic association. Zinc, $\mathrm{Co}, \mathrm{Li}, \mathrm{Mn}, \mathrm{Ni}, \mathrm{Pb}$ and $\mathrm{V}$ are bound $100 \%$ to mineral matter, while $\mathrm{Cd}, \mathrm{Cr}$ and $\mathrm{Cu}$ are bound $100 \%$ to organic matter. Berrilium only was found to have values in the range of $30 \%$ organic and $70 \%$ inorganic In Longyearbyen coals $\mathrm{Cr}$ and and $\mathrm{V}$ are $100 \%$ 
bound to inorganic fractions, while $\mathrm{Be}, \mathrm{Co}, \mathrm{Cu}$, and $\mathrm{Ni}$ are bound $100 \%$ to the organic fraction. Zinc, $\mathrm{Cd}, \mathrm{Li}, \mathrm{Mn}$ and $\mathrm{Pb}$ show variable affinity to both fractions in these coals.

Huggins et al [15] determined modes of occurrence of some major and trace metals in an Illinois coal and fractions obtained by several physical separation techniques. They observed that $\mathrm{K}$ and Fe were present entirely in inorganic forms. Calcium was present from 80 to $90 \%$ in inorganic form; the remainder was present as bound to carboxyl groups. Chromium and $\mathrm{V}$ were present predominantly in inorganic forms, with minor amounts having organic association (5$10 \% \mathrm{Cr}, 20-30 \% \mathrm{~V})$. Arsenic and $\mathrm{Zn}$ were present almost entirely in inorganic forms distributed among various inorganic minerals.

Our earlier studies [ 16,17] of extraction of these coal samples with different leachants showed that trace metals like $\mathrm{Cu}, \mathrm{Zn}, \mathrm{Mn}, \mathrm{Fe}$, $\mathrm{Mg}, \mathrm{K}$ and $\mathrm{Na}$ were present both as as ionexchangeable cations (extractable with ammonium acetate) and as part of discretemineral particles (extractable with acids). The amounts of ion-exchangeable metals however were quite less compared to their respective amounts present as discrete mineral particles. Our earlier work on Scanning Electron Microscopic studies [18] of virgin coal samples and coal samples after extraction with different leachants, pointed to the existence of homogeneously distributed network of mineral matter in the organic matrix of coal, comprised of micro filamentous crystallites (discrete mineral particles) and as surface coverage (ion-exchangeable cation). Furthermore SEM micrographs of coal samples extracted with ammonium acetate revealed surface disintegration in the form of micro fissures, cracks, crevices and valleys which indicated the extraction of organically bound elements.

In our earlier studies [19], using float and sink separation for four Pakistani coals, it was observed that Makarwal and Sor-Range coals had the highest amount of ash forming materials in the float fraction, where as in Degari and Shahrigh coal samples, most of the ash forming material were found to be enriched in the sink fraction, this showed that in Makarwal and Sor-Range coal samples, most of the ash forming material might be present in close association with the coal structure. On the other hand, in case of Degari and Shahrigh coal samples, significant amount of their ash forming material might have been present as discrete mineral matter. In the present work the ash of float and sink fractions of the four Pakistani coal samples have been analyzed for some trace metals in continuation to our earlier work in an attempt to know, whether these elements are bound organically or occur as part of the discrete mineral matter.

\section{EXPERIMENTAL}

\subsection{Float and Sink SeParation of Coal SAMPLES}

Representative coal samples obtained through Pakistan Mineral Development Corporation from four coal mines in Pakistan were studied in the present investigation.

Selected coal lumps free from visible lumps of inorganic matter were used for float and sink analysis in order to avoid the mineral matter inclusions due to roofs and floors of coal mines as were present in the representative samples. The coal samples were crushed in a pestle and mortar and were screened through $0.6 \mathrm{~mm}$ and $0.3 \mathrm{~mm}$ screens using a vibrating shaking screen. The products which passed through $0.6 \mathrm{~mm}$ screen and retained on $0.3 \mathrm{~mm}$ screen were dried at $110{ }^{\circ} \mathrm{C}$ and used 
for washability studies using media of different specific gravities [19].

\subsection{SAMPLE SOLUTION PREPARATION}

The various float and sink fractions as well as the whole coal sample were ashed at $750{ }^{\circ} \mathrm{C}$ in a muffle furnace for $2-4 \mathrm{hrs}$ and the resulting ash was weighed. The ash from the various fractions were dissolved by digesting with $\mathrm{HF}$ and $\mathrm{H}_{2} \mathrm{SO}_{4}$ in a platinum crucible to volatilize silica and then treated with $\mathrm{HCl}$ to solubilize the trace metals present in the ash. The solutions were diluted to $100 \mathrm{~cm}^{3}$ with distilled water and stored in polyethylene bottles for trace metals analysis.

\subsection{Trace Metals Determination}

Trace metals in the sample solutions prepared above, were determined using a Pye Unicam Model SP 191 Atomic Absorption Spectrophotometer. Working sample solutions were prepared by diluting appropriate volumes of the original filtrate with distilled water so as to get reading within the range of working standards.

Standard stock solution for various metals were prepared by dissolving pure metal or their salts of Analar or chemical reagent grades according to standard procedure of solution preparation for Atomic Absorption Spectrophotometer. Four working standard solutions were prepared for each metal in the concentration range of $1-5 \mathrm{ppm}(\mathrm{Cu}), 1-5$ ppm (Ni), 1-5 ppm ( $\mathrm{Zn})$ and 1-5 ppm (Co) by diluting appropriate volume of the stock solution with distilled water. The operational conditions for metal determination by Atomic absorption Spectrophotometer is give in Table 1.

TABlE 1: OpERATIONAL CONDITIONS FOR METAL DETERMINATION

\begin{tabular}{|l|l|l|l|l|}
\hline Metal & Flame Used & $\begin{array}{c}\text { Slit } \\
\text { Width } \\
\text { (nm) }\end{array}$ & $\begin{array}{c}\text { Wavelength } \\
\text { (nm) }\end{array}$ & Sensitivity \\
\hline $\mathrm{Cu}$ & Air/Acetylene & 0.2 & 324.75 & 0.025 \\
\hline $\mathrm{Ni}$ & Air/Acetylene & 0.2 & 232.00 & 0.05 \\
\hline $\mathrm{Zn}$ & Air/Acetylene & 0.2 & 213.88 & 0.009 \\
\hline $\mathrm{Co}$ & Air/Acetylene & 0.2 & 240.72 & 0.06 \\
\hline
\end{tabular}

\section{RESULTS AND DISCUSSION}

The analysis of four representative Pakistani coal samples obtained from Makarwal, Shahrigh, Sor-Range, and Degari coal mines is given in Table 2 .

TABle 2: ANALysis of Four Representative PAKISTANi CoAl SAMPles

\begin{tabular}{|l|l|l|l|l|}
\hline Analysis/Sample & Makarwal & Shahrigh & Sor-Range & Degari \\
\hline Moisture(as received) \% & 4.12 & 4.67 & 9.37 & 8.09 \\
\hline Moisture holding capacity \% & 6.13 & 9.00 & 13.00 & 12.70 \\
\hline Volatile Combustible Matter V.C.M (as received) \% & 43.08 & 42.15 & 46.13 & 40.78 \\
\hline V.C. M (Dry, MM free) \% & 48.22 & 66.60 & 54.60 & 52.30 \\
\hline Ash (Rep. Sample) \% & 4.12 & 26.85 & 5.27 & 10.95 \\
\hline Ash (Select. Lump sample) \% & 1.95 & 13.27 & 5.37 & 9.26 \\
\hline Ash (R.O.M.) Sample \% & 24.00 & 33.50 & 13.93 & 38.67 \\
\hline Mineral Matter (Parr Formula) \% & 6.55 & 32.04 & 6.15 & 13.94 \\
\hline Fixed Carbon (As Received) \% & 48.68 & 26.33 & 39.23 & 40.18 \\
\hline Fixed Carbon (Dry MM free) \% & 53.85 & 40.29 & 46.28 & 50.79 \\
\hline Calorific Value (As Received) (Kcals/kg) & 6651 & 4553 & 5596 & 5526 \\
\hline Calorific Value (Moist. MM Free) (kcals/kg) & 5328 & 3075 & 4477 & 4596 \\
\hline Total S (Eschka Method) \% & 3.82 & 5.53 & 0.84 & 3.84 \\
\hline Total S (Bomb Combust. Method) \% & 3.80 & 5.48 & 0.83 & 3.81 \\
\hline Sulphatic S \% & 0.14 & 0.89 & 0.05 & 0.15 \\
\hline Pyretic S \% & 0.02 & 0.64 & 0.16 & 0.34 \\
\hline Organic S \% & 3.66 & 4.00 & 0.63 & 3.35 \\
\hline Total Cl (Eschka Method) \% & 0.12 & 0.24 & 0.19 & 0.24 \\
\hline Total Cl (Bomb Combust. Method) \% & 0.12 & 0.24 & 0.20 & 0.24 \\
\hline
\end{tabular}

V.C.M- Volatile combustible matter, MM free- Mineral matter free, R.O.M.- Run of mine, Parr formula- $\% \mathrm{MM}=1.08 \mathrm{~A}+0.55 \mathrm{~S}$ (MM- Mineral Matter, A- Percentage of Ash in the Sample, S- Percentage of Total Sulfur in the Sample). 
The analysis given in Table 2, shows that these coals have low calorific value, high volatile matter, high ash and high sulfur content, and range from lignite to sub bituminous in rank. The ash content of the representative samples, selected lump samples and run of mine (ROM) samples show considerable difference. The ash content of the run of mine samples is appreciably high compared to the representative and selected lump. The various forms of sulfur present in these coals have also been given in Table 2, which indicates that all these coals contain sulfur in the form of pyretic, sulphatic and organic forms. The organic sulfur is present in appreciable amount in all the four coal samples compared to pyretic and sulphatic forms. The concentrations of $\mathrm{Co}, \mathrm{Cu}, \mathrm{Ni}$, and $\mathrm{Zn}$ determined in the selected whole coal lump samples are given in Table 3 and Fig. 1. The world averages reported for these metals by Dai et al [6] have also been included in the table for comparison.

Table 3: Trace Metals Contents in WhOle COAL OF FOUR PAKISTANI COAL SAMPLES

\begin{tabular}{|c|c|c|c|c|c|}
\hline $\begin{array}{c}\text { Coal } \\
\text { Sample }\end{array}$ & $\%$ Ash & $\begin{array}{c}\mathrm{Co} \\
(\boldsymbol{\mu g} / \mathrm{g})\end{array}$ & $\begin{array}{c}\mathrm{Cu} \\
(\boldsymbol{\mu} \mathrm{g} / \mathrm{g})\end{array}$ & $\begin{array}{c}\mathrm{Ni} \\
(\boldsymbol{\mu} \mathrm{g} / \mathrm{g})\end{array}$ & $\begin{array}{c}\mathrm{Zn} \\
(\boldsymbol{\mu} \mathrm{g} / \mathrm{g})\end{array}$ \\
\hline $\begin{array}{c}\text { Makarwal } \\
\text { Coal }\end{array}$ & 1.95 & 6 & 20 & 10 & 30 \\
\hline $\begin{array}{c}\text { Shahrigh } \\
\text { Coal }\end{array}$ & 13.27 & 10 & 30 & 50 & 60 \\
\hline $\begin{array}{c}\text { Sor-Range } \\
\text { Coal }\end{array}$ & 5.37 & 8 & 20 & 10 & 20 \\
\hline $\begin{array}{c}\text { Degari } \\
\text { Coal }\end{array}$ & 9.62 & 10 & 20 & 40 & 60 \\
\hline $\begin{array}{c}\text { World } \\
\text { Average }\end{array}$ & $-\cdots$ & 5.1 & 16 & 13 & 23 \\
\hline
\end{tabular}

The results show that most of the metals have high concentration in the four coal samples compared to their respective values of the world average. The $\mathrm{Zn}$ and $\mathrm{Ni}$ contents in Shahrigh and Degari coals are high compared to their respective amounts in Makarwal and
Sore-Range coals. The $\mathrm{Zn}$ content is appreciably high in all the four coal samples compared to the world average. The $\mathrm{Ni}$ content is appreciably high compared to the world average in case of Sharigh and Degari coals, whereas Makarwal and Sore-range coals have lower values compared to the world average.

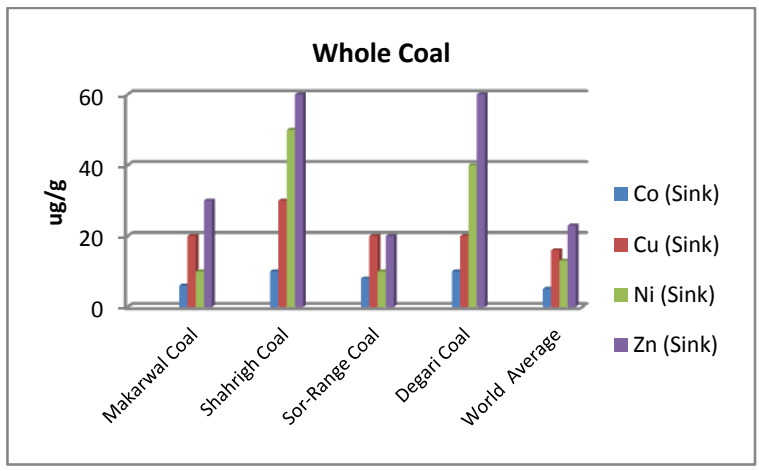

Fig.1. Concentration of Trace Elements in Whole Coal

Table 4 and Fig. 2 show the float and sink fractions of Makarwal coal at different specific gravities.

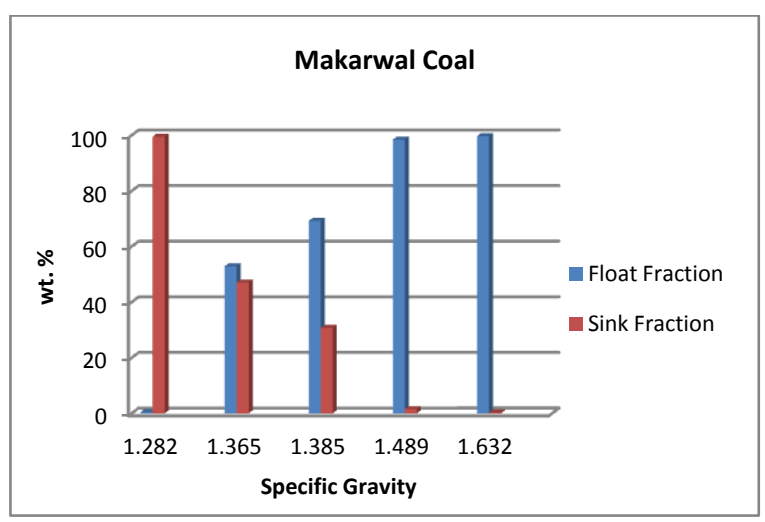

Fig.2. Weight Percentage of Float and Sink Fractions in Makarwal Coal at Different Specific Gravities

The results show that float fraction is quite low at the lowest specific gravity (sp.g 1.282), whereas most of coal is present in the sink fraction. The percentage of float fraction has increased with increase in specific gravity of the medium. At the highest specific gravity (sp.g.1.632), the coal is present almost in the float fraction (99.65). The sink fraction is quite negligible. 
Table 4: Trace Metals Contents in Float and Sink Fractions of Makarwal Coal.

\begin{tabular}{|c|c|c|c|c|c|c|}
\hline Float/ Sink Fractions & Fractions Wt\% & \%Ash & Co $(\mu g / g)$ & $\mathrm{Cu}(\mu \mathrm{g} / \mathrm{g})$ & $\mathrm{Ni}(\mu \mathrm{g} / \mathrm{g})$ & $\mathrm{Zn}(\mu \mathrm{g} / \mathrm{g})$ \\
\hline Float Fraction (Sp.G.1.282) & 0.50 & $\ldots$ & $\ldots$ & $\ldots$ & $\ldots$ & $\ldots$ \\
\hline Sink Fraction (Sp.G.1.282) & 99.50 & 2.29 & 5 & 15 & 5 & 46 \\
\hline Float Fraction (Sp.G.1.365) & 52.92 & 0.96 & 10 & 14 & 9 & 28 \\
\hline Sink Fraction (Sp.G.1.365) & 47.08 & 3.18 & 11 & 28 & 17 & 90 \\
\hline Float Fraction (Sp.G.1.385) & 69.26 & 1.21 & 7 & 14 & 14 & 43 \\
\hline Sink Fraction Sp.G.1.385) & 30.74 & 3.68 & 19 & 25 & 24 & 107 \\
\hline Float Fraction (Sp.G.1.489) & 98.48 & 1.53 & 5 & 13 & 5 & 40 \\
\hline Sink Fraction (Sp.G.1.489) & 1.52 & $\ldots$ & $-\cdots$ & $-\cdots$ & $-\cdots$ & $-\cdots$ \\
\hline Float Fraction (Sp.G.1.632) & 99.65 & 1.83 & 8 & 13 & 5 & 15 \\
\hline Sink Fraction (Sp.G1.632) & 0.35 & $\cdots$ & $\ldots$ & $\ldots$ & $\ldots$ & $\ldots$ \\
\hline
\end{tabular}

The weight percentage of ash in the float and sink fractions in Makarwal coal at different specific gravities given in Table4 and illustrated in Fig.3, show that the ash percentage is negligibly small in the float fraction at the lowest specific gravity of 1.282 . A gradual increase in the ash percentage in the float fractions can be easily noticed with increase in specific gravity of the medium.

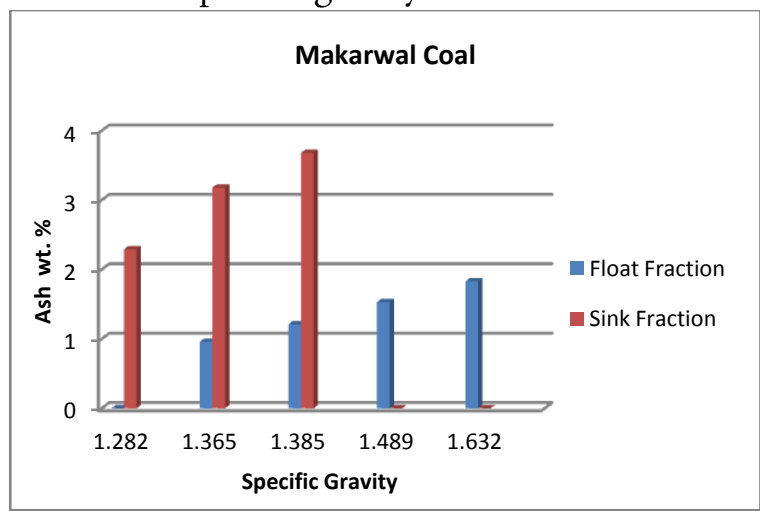

Fig.3. Weight Percentage of Ash in Float and Sink Fractions in Makarwal Coal at Different Specific Gravities

The ash percentage in the sink fractions show an initial increase and then decrease with increase in specific gravity of the medium. The ash percentage in the float fraction is highest at the specific gravity 1.632 , whereas in the sink fractions it is highest at the specific gravity 1.385 . At the highest specific gravity of 1.632, ash percentage in the sink fraction is almost negligible. The negligibly small percentages of ash in the float fraction at specific gravity 1.282 and the sink fraction at specific gravity 1.632 is because of their respective negligibly small weight fractions at these specific gravities. These results also indicate that in Makarwal coal, almost all of the ash forming material is closely associated with the organic coaly matter. Discrete mineral particles if present would have been substantially concentrated in the sink fraction at the highest specific gravity.

The concentrations of trace elements in the float and sink fractions at different specific gravities of Makarwal coal are included in Table 4 and illustrated in Fig.4.

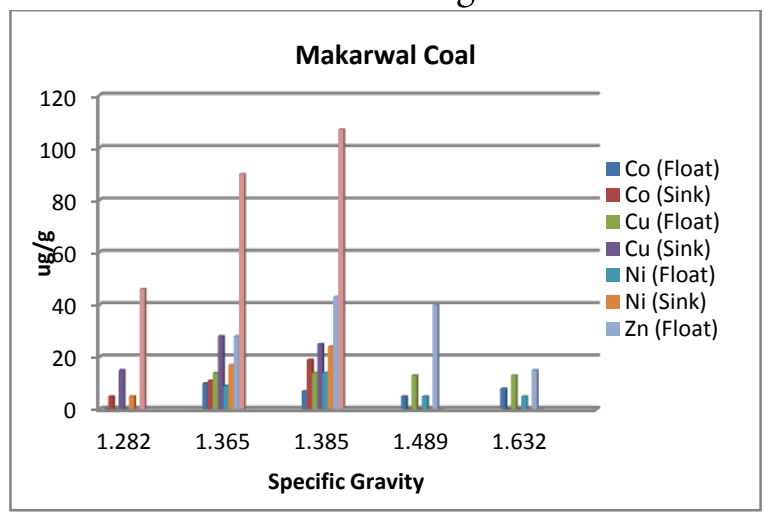

Fig.4. Concentration of Trace Elements in Float and Sink Fractions of Makarwal Coal at Different Specific Gravities

The results show that at specific gravities 1.282 and 1.632, almost all metals are present respectively in the sink and float fractions. These are in accordance to their respective float and sink weight fractions (Fig.2) and ash percentage of float and sink fractions (Fig.3) at different specific gravities. Figure 4 clearly 
shows that $\mathrm{Zn}$ is present in highest concentration in almost all fractions compared to other metals. Increase in concentration of all metals can be noticed both in the float and sink fractions with increase in specific gravity of the medium till specific gravity 1.385. Further increase in specific gravity caused a decrease in their respective concentration. These are in accordance to the results of ash percentage of float and sink fractions at different specific gravities (Fig.3). Almost all the metals show high concentration in the sink fractions at specific gravities 1.3655 and 1.385. High concentration of metals at these specific gravities might be due to the high specific gravity of the coaly matter to which these metals are associated in high concentration, compared to the specific gravity of the coaly matter having less concentration of these metals. The unexpected low values of trace metals in the float fraction in medium of specific gravity 1.632 might be due to retainment of the float-sink liquid medium in the coal fraction which was not completely removed by drying at $110{ }^{\circ} \mathrm{C}$ for calculating the percentage of weight fractions.

Table 5 and Fig. 5 show the float and sink fractions of Shahrigh coal at different specific gravities.

The results show that float fraction is quite low at the lowest specific gravity (sp.g 1.282), whereas most of the coal is present in the sink fraction at this specific gravity, similar to Makarwal coal. In Sharigh coal the float fraction at this specific gravity is $10.05 \%$ compared to $0.5 \%$ in Makarwal coal at the same specific gravity. The percentage of float fractions has increased with increase in specific gravity of the medium, whereas the percentage of sink fractions has decreased. At the highest specific gravity (sp.g.1.632), $15.97 \%$ of coal is present in the sink fraction compared to $0.35 \%$ in case of Makarwal coal, indicating that comparatively high inorganic matter is present as discrete mineral particles which settle down at the highest specific gravity.

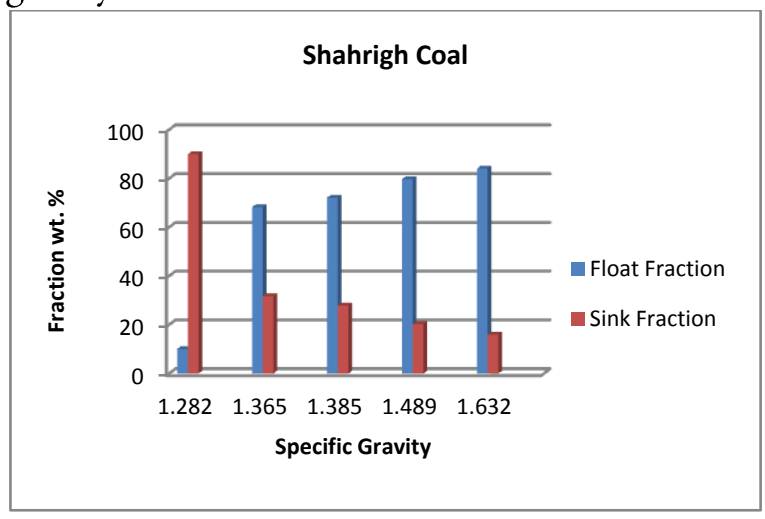

Fig.5. Weight Percentage of Float and Sink Fractions in Shahrigh Coal at Different Specific Gravities

The weight percentage of ash in the float and sink fractions at different specific gravities is given in Table 5 and illustrated in Fig.6.

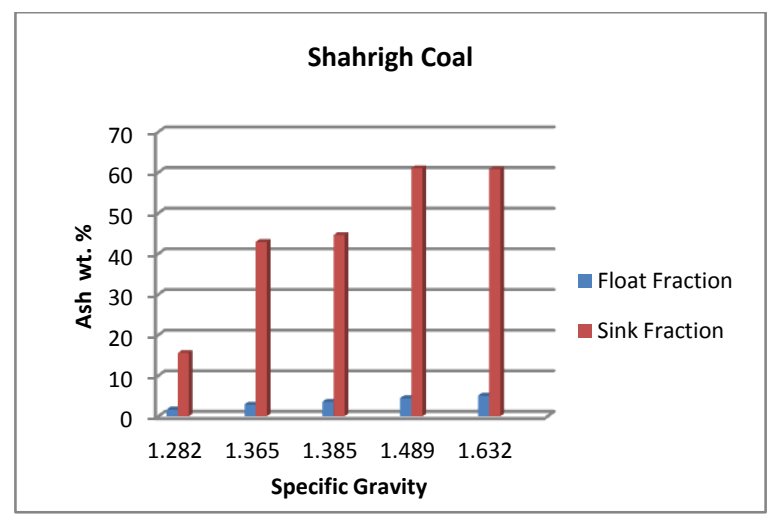

Fig.6. Weight Percentage of Ash in Float and Sink Fractions in Shahrigh Coal at Different Specific Gravities

The ash percentage in the float fractions is almost constant at all the specific gravities in contrast to that in Makarwal coal which shows an increasing trend with increase in specific gravity of the medium. It is to be pointed out that percent ash is significantly high in whole coal and the various fractions, especially the sink fractions in case of Shahrigh coal compared to Makarwal coal. A gradual increase in the ash percentage in the sink fraction can be noticed with increase in specific gravity of the medium. The ash 
percentage at the specific gravity 1.489 and 1.632 are quite high compared to Makarwal coals. The results show that in contrast to Makarwal coal, a significant fraction of the inorganic matter in this coal may be present in the form of discrete mineral particles which settle easily in the liquid medium of high specific gravity. The concentration of trace elements in the float and sink fractions at different specific gravities of Shahrigh coal is included in Table 5 and illustrated in Fig.7.

Table 5: Trace Metals Contents in Float and Sink Fractions of Shahrigh Coal.

\begin{tabular}{|l|c|c|c|c|c|c|}
\hline Float/ Sink Fractions & Fractions Wt\% & \%Ash & Co $(\boldsymbol{\mu g} / \mathbf{g})$ & $\mathrm{Cu}(\boldsymbol{\mu g} / \mathbf{g})$ & $\mathrm{Ni}(\boldsymbol{\mu g} / \mathbf{g})$ & $\mathrm{Zn}(\boldsymbol{\mu g} / \mathbf{g})$ \\
\hline Float Fraction (Sp.G1.282) & 10.05 & 1.69 & 11 & 11 & $\ldots-$ & 6 \\
\hline Sink Fraction (Sp.G.1.282) & 89.95 & 15.58 & 34 & 34 & 30 & 21 \\
\hline Float Fraction (Sp.G1.365) & 68.26 & 2.89 & --- & 7 & 7 & 7 \\
\hline Sink Fraction (Sp.G1.365) & 31.74 & 42.90 & 32 & 40 & 79 & 47 \\
\hline Float Fraction (Sp.G.1.385) & 72.11 & 3.56 & 7 & 7 & 7 & 7 \\
\hline Sink Fraction (Sp.G.1.385) & 27.89 & 44.60 & 33 & 47 & 92 & 66 \\
\hline Float Fraction (Sp.G.1.489) & 79.71 & 4.46 & --- & 25 & 9 & 19 \\
\hline Sink Fraction (Sp.G.1.489) & 20.29 & 61.05 & 35 & 29 & 115 & 93 \\
\hline Float Fraction (Sp.G.1.632) & 84.03 & 5.08 & 6 & 9 & 15 & 12 \\
\hline Sink Fraction (Sp.G.1.632) & 15.97 & 60.80 & 46 & 60 & 125 & 75 \\
\hline
\end{tabular}

The results show a progressive increase in the $\mathrm{Ni}$ and $\mathrm{Zn}$ contents in the sink fractions with increase in specific gravity of the medium. The $\mathrm{Ni}$ concentration, however is less at the highest specific gravity 1.632 compared to its value at the specific gravity 1.489 . Of the four metals, $\mathrm{Ni}$ is present in the highest concentration in the sink fractions at the specific gravities $1.365,1.385,1.489$ and 1.632. The concentrations of all the metals are appreciably high compared to their amounts in Makarwal coal. The comparatively higher trace metal contents at the high specific gravities is in conformity to the higher weight percentage of ash at high specific gravities in this coal (Fig.6). The results also show, that where as $\mathrm{Zn}$ is present in the highest concentration in the sink fractions at all the specific gravities in case of Makarwal coal, $\mathrm{Ni}$ is present in the highest concentrations in the sink fractions at all the specific gravities in case of Shahrigh coal. High metal contents in the sink fractions especially $\mathrm{Ni}$ and $\mathrm{Zn}$ indicate that major part of these metals may be present in close association with the inorganic matter in this coal.
Table 6 and Fig. 8 show the float and sink fractions of Sore-Range coal at different specific gravities.

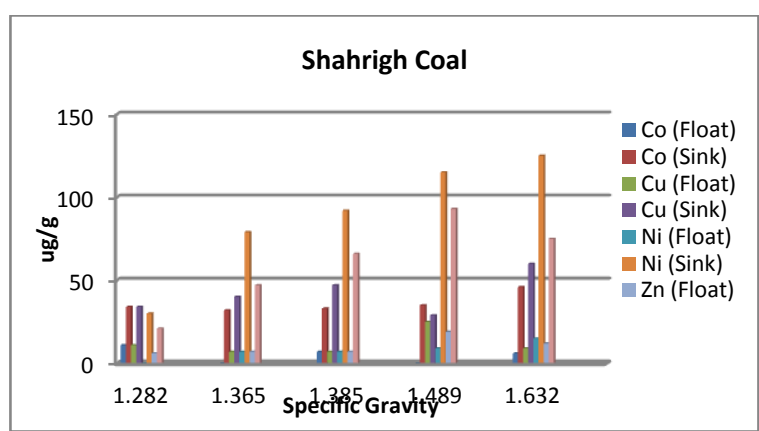

Fig.7. Concentration of Trace Elements in Float and Sink Fractions of Shahrigh Coal at Different Specific Gravities

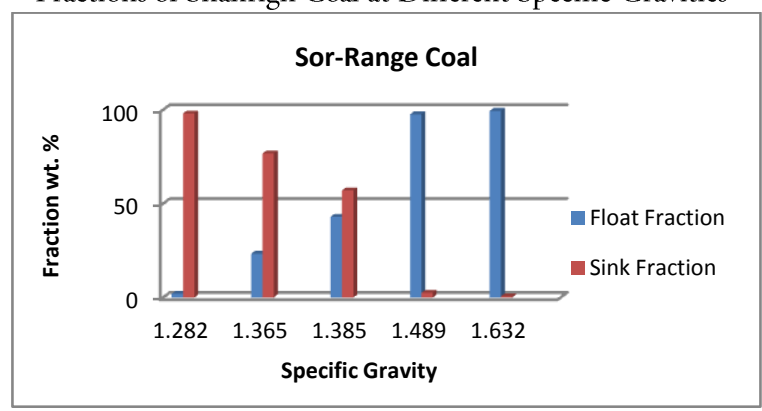

Fig.8. Weight Percentage of Float and Sink Fractions in SorRange Coal at Different Specific Gravities

Sore range coal shows behavior similar to Makarwal coal. The float fraction is the lowest at the lowest specific gravity of 1.282 , whereas the sink fraction is the lowest at the highest 
specific gravity of 1.632. A progressive increase in the float fraction and a decrease in the sink fraction can be noticed with increase in specific gravity of the medium.

TAble 6: Trace Metals Contents in Float and Sink Fractions of Sor-Range Coal.

\begin{tabular}{|c|c|c|c|c|c|c|}
\hline Float/ Sink Fractions & Fractions $\mathrm{Wt} \%$ & \%Ash & Co $(\mu \mathrm{g} / \mathrm{g})$ & $\mathrm{Cu}(\mu \mathrm{g} / \mathrm{g})$ & $\mathrm{Ni}(\mu \mathrm{g} / \mathrm{g})$ & $\mathrm{Zn}(\mu \mathrm{g} / \mathrm{g})$ \\
\hline Float Fraction (Sp.G.1.282) & 2.00 & $\ldots$ & $\ldots$ & $\ldots$ & $\ldots$ & $\ldots$ \\
\hline Sink Fraction (Sp.G.1.282) & 98.00 & 5.58 & 10 & 26 & 23 & 30 \\
\hline Float Fraction (Sp.G.1.365) & 23.30 & 4.19 & $\ldots$ & 22 & $\ldots$ & 31 \\
\hline Sink Fraction (Sp.G.1.365) & 76.70 & 6.01 & 7 & 32 & 19 & 23 \\
\hline Float Fraction (Sp.G.1.385) & 43.00 & 3.65 & 12 & 22 & 12 & 44 \\
\hline Sink Fraction (Sp.G.1.385) & 57.00 & 6.98 & 9 & 26 & 9 & 16 \\
\hline Float Fraction (Sp.G.1.489) & 97.57 & 4.10 & 8 & 21 & 8 & 8 \\
\hline Sink Fraction (Sp.G.1.489) & 2.43 & $-\ldots$ & $\ldots$ & $\ldots$ & $\ldots$ & $-\cdots$ \\
\hline Float Fraction (Sp.G.1.632) & 99.40 & 4.47 & 10 & 30 & 15 & 23 \\
\hline Sink Fraction (Sp.G.1.632) & 0.60 & $-\ldots$ & $\ldots$ & $-\cdots$ & $-\ldots$ & $-\cdots$ \\
\hline
\end{tabular}

The weight percentage of ash in the float and sink fractions at different specific gravities is given in Table 6 and illustrated in Fig. 9.

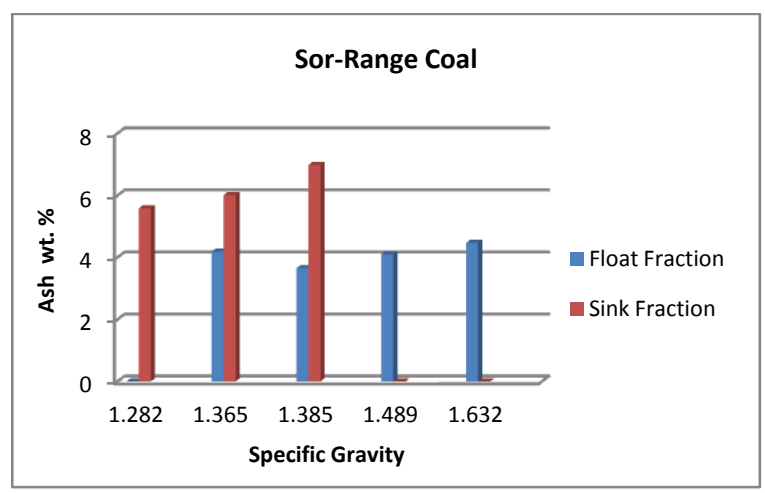

Fig.9. Weight Percentage of Ash in Float and Sink Fractions in Sor-Range Coal at Different Specific Gravities

The weight percentage of ash in the float and sink fractions follow a pattern similar to Makarwal Coal. A progressive increase in ash percentage of the float fractions with increase in specific gravity of the medium can be noticed. The ash percentage in the sink fractions shows an increasing trend with increase in specific gravity, till it reaches to its highest value at 1.385 . Further increase in specific gravity caused a decrease in the ash percentage.

The negligibly small percentages of ash in the float fraction at specific gravity 1.282 and the sink fraction at specific gravity 1.632 is because of their respective negligibly small weight fractions at these specific gravities as noticed in Makarwal coal. The ash percentage of the float and sink fractions in Sore-Range coal indicates that substantial amount of the inorganic matter may be closely associated with the organic coaly matter similar to Makarwal coal. Sore-Range coal has significantly low percent ash content in whole coal and in the various float and sink fractions as compared with their respective values in case of Shahrigh coal.

The concentration of trace elements in the float and sink fractions at different specific gravities of Sore-Range coal is included in Table 6 and illustrated in Fig. 10.

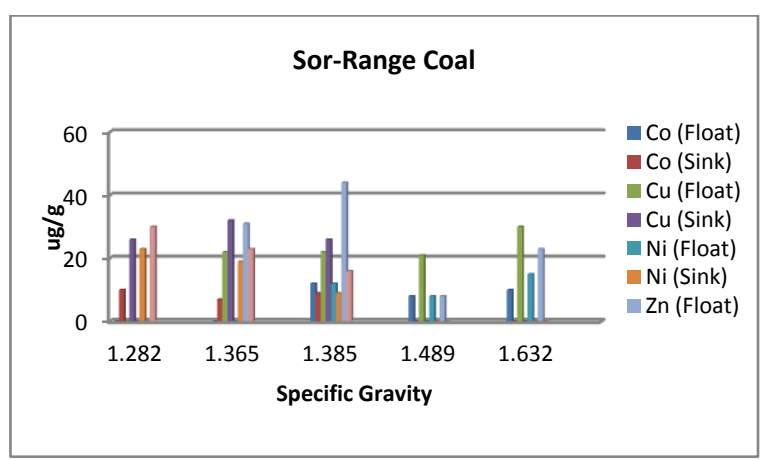

Fig.10. Concentration of Trace Elements in Float and Sink Fractions of Sor-Range Coal at Different Specific Gravities

The results show that at specific gravities 1.282 and 1.632, almost all metals are present respectively in the sink and float fractions similar to Makarwal coal. The trace metals in 
the float fraction at the lowest specific gravity 1.282 and in the sink fraction of the highest specific gravity 1.632 were not detected. In the mid specific gravity of 1.385 , all metals are present appreciably in both the float and sink fractions, similar to Makarwal coal. The results also show that in Sore-Range coal $\mathrm{Zn}$ is present in the highest concentration compared to other metals. Zinc was also found in highest concentration in most of the fractions in Makarwal coal.

The almost zero values of all the trace metals in the sink fraction at the highest specific gravity 1.632 indicate that in Sore-Range coal almost all the trace metals may be present in close association to the organic structure of coal similar to Makarwal coal.
The float and sink fractions at different specific gravities of Degari coal is given in Table 7 and Fig. 11.

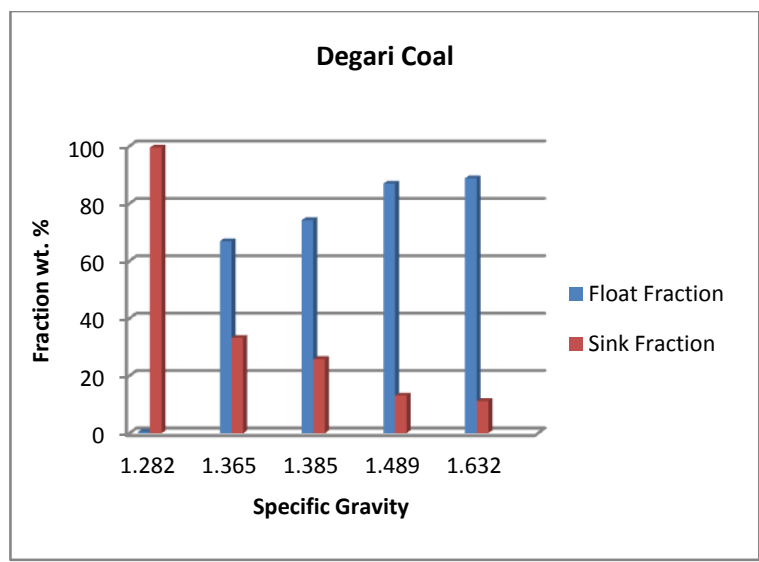

Fig.11. Weight Percentage of Float and Sink Fractions in Degari Coal at Different Specific Gravities

Table 7: Trace Metals Contents in Float and Sink Fractions of Degari Coal.

\begin{tabular}{|c|c|c|c|c|c|c|}
\hline Float/ Sink Fractions & Fractions $\mathrm{Wt} \%$ & $\%$ Ash & Co $(\mu \mathrm{g} / \mathrm{g})$ & $\mathrm{Cu}(\mu \mathrm{g} / \mathrm{g})$ & $\mathrm{Ni}(\mu \mathrm{g} / \mathrm{g})$ & $\mathrm{Zn}(\mu \mathrm{g} / \mathrm{g})$ \\
\hline Float Fraction (Sp.G.1.282) & 0.51 & $\ldots$ & $-\ldots$ & $\ldots$ & $\ldots$ & $\ldots$ \\
\hline Sink Fraction (Sp.G.1.282) & 99.49 & 8.21 & 5 & 15 & 15 & 29 \\
\hline Float Fraction (Sp.G.1.365) & 66.82 & 3.33 & $\ldots$ & 15 & 8 & 29 \\
\hline Sink Fraction (Sp.G.1.365) & 33.18 & 23.25 & 38 & 28 & 46 & 77 \\
\hline Float Fraction (Sp.G.1.385) & 74.20 & 3.53 & $\ldots$ & 10 & 13 & 14 \\
\hline Sink Fraction (Sp.G.1.385) & 25.80 & 31.03 & 18 & 87 & 46 & 148 \\
\hline Float Fraction (Sp.G.1.489) & 86.92 & 3.74 & $\ldots$ & 14 & 6 & 14 \\
\hline Sink Fraction (Sp.G.1.489) & 13.08 & 50.23 & 125 & 21 & 248 & 186 \\
\hline Float Fraction (Sp.G.1.632) & 88.80 & 4.49 & 6 & 39 & 8 & 11 \\
\hline Sink Fraction (Sp.G.1.632) & 11.20 & 60.31 & 140 & 832 & 273 & 898 \\
\hline
\end{tabular}

An increasing trend in the weight percentage of float fraction and a decreasing trend of the sink fraction can be noticed similar to other coals.

The weight percentage of ash in the float and sink fractions at different specific gravities is given in Table 7 and illustrated in Fig. 12. The ash percentage in the whole coal and the various float and sink fractions is significantly high compared to their respective values in case of Makarwal and Sore-Range coals and almost similar to Sharigh coal. An increasing trend in the percent ash in the sink fraction with increase in specific gravity of the medium can be seen. The trend is similar to that observed in Sharigh coal. A considerable enrichment of the ash forming inorganic matter has occurred in the sink fractions at high specific gravities.

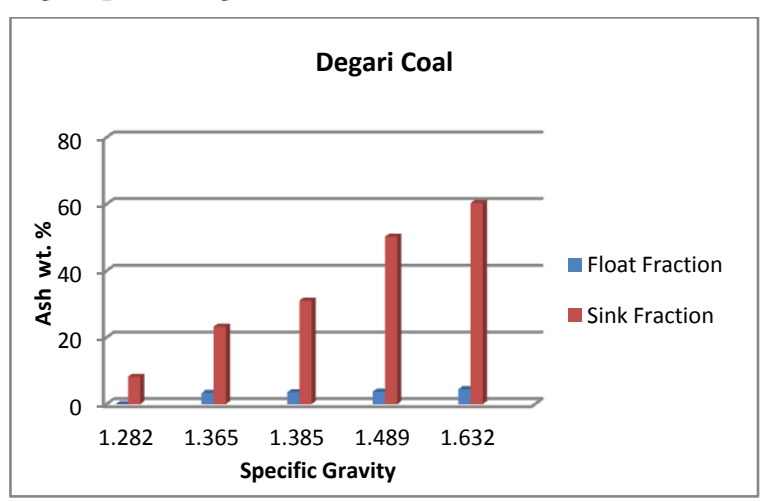

Fig.12. Weight Percentage of Ash in Float and Sink Fractions in Degari Coal at Different Specific Gravities

This indicates that similar to Sharigh coal a significant part of the inorganic matter might 
be present as discrete mineral matter, which can easily be separated as sink fraction in medium of high specific gravities.

The concentrations of trace elements in the float and sink fractions at different specific gravities of Degari coal are included in Table 7 and illustrated in Fig.13.

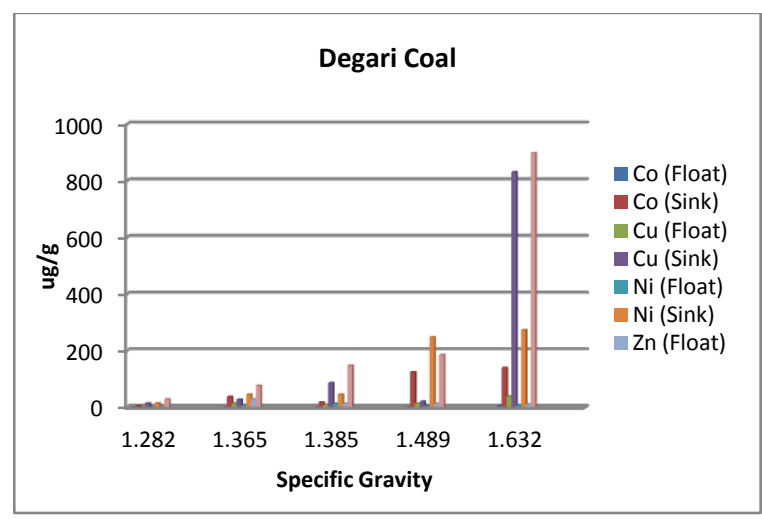

Fig.13. Concentration of Trace Elements in Float and Sink Fractions of Degari Coal at Different Specific Gravities

An increase in concentration of trace metals has occurred in the sink fractions with increase in specific gravity of the medium, similar to Shahrigh coal. The concentration of $\mathrm{Cu}$ and $\mathrm{Zn}$ in Degari coal is quite large in sink fractions at the highest specific gravity 1.632. High concentration of trace metals especially $\mathrm{Cu}$ and Zinc at higher specific gravities indicates that most part of these elements might be present as part of discrete mineral particles, which can easily be separated from organic coaly matter in medium of high specific gravities.

Figure 14 shows the weight percentage of float fractions at different specific gravities in different coal samples. An increasing trend can be noticed in all the coal samples with increase in specific gravity of the medium. The float fractions are highest in the two higher specific gravities. Figure 15 shows weight percentage of ash in float fractions in medium of different specific gravities of the four coal samples.

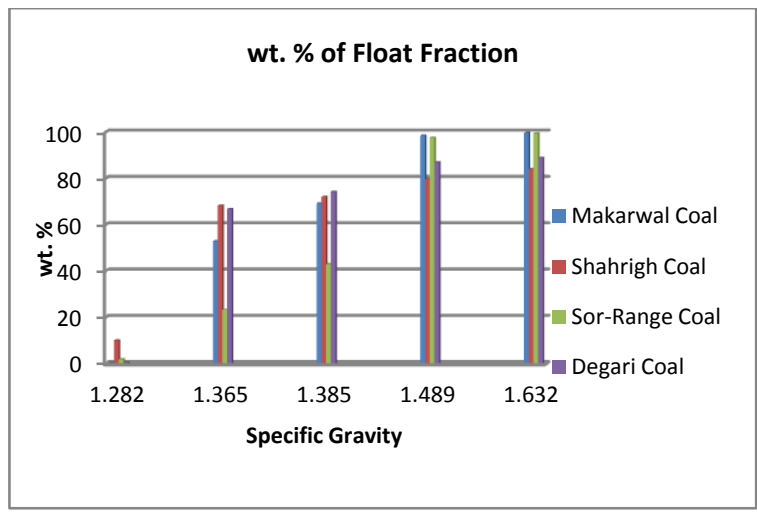

Fig.14. Weight Percentage of Float Fractions in Different Coal Samples at Different Specific Gravities

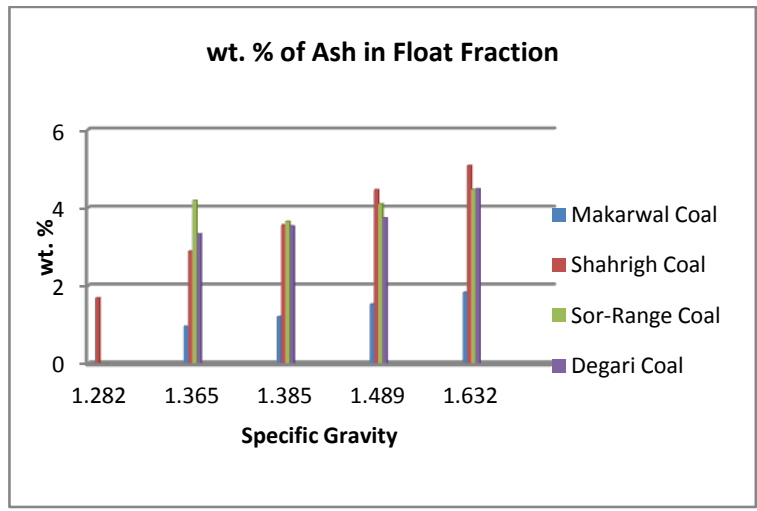

Fig.15. Weight Percentage of Ash in Float Fractions in Different Coal Samples at Different Specific Gravities

An increase can be noticed in the percent ash with increase in specific gravity of the medium.

The concentration of trace elements in the float fractions of all the coal samples at different specific gravities is shown in Fig.16. The figure shows that concentration of trace metals especially $\mathrm{Zn}$ was appreciably high in the float fractions at specific gravities 1.385 and 1.489 in case of Makarwall and SoreRange coal samples.

Other coals show variable concentration of trace metals at different specific gravities in the float fractions. 


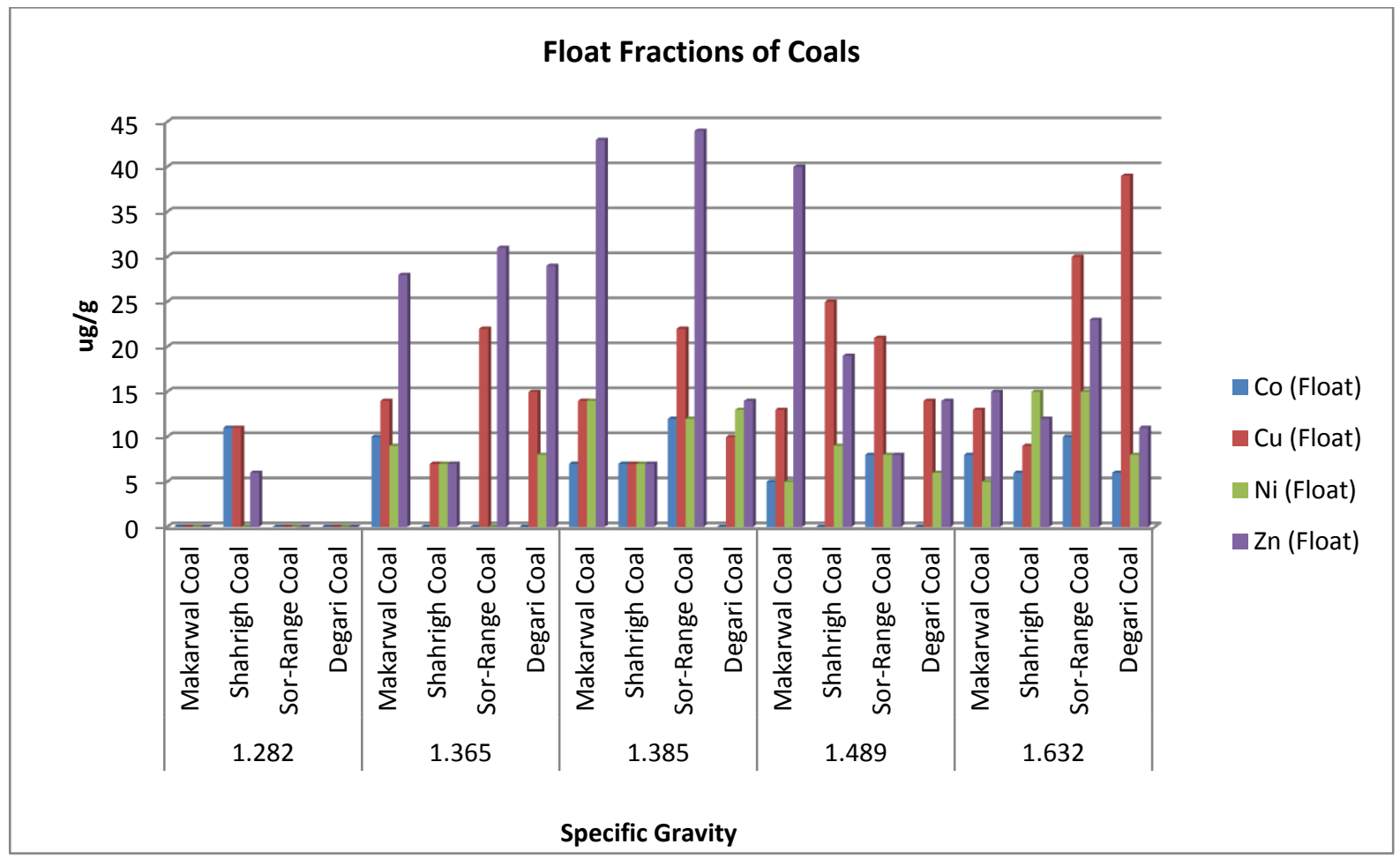

Fig.16. Concentration of Trace Elements in Float Fractions of Coal Samples

Figure 17 shows weight percentage of sink fractions of different coals at different specific gravities. A decreasing trend can be noticed in the weight percentages of sink fractions of most of the coals with increase in specific gravity of the medium as discussed earlier.

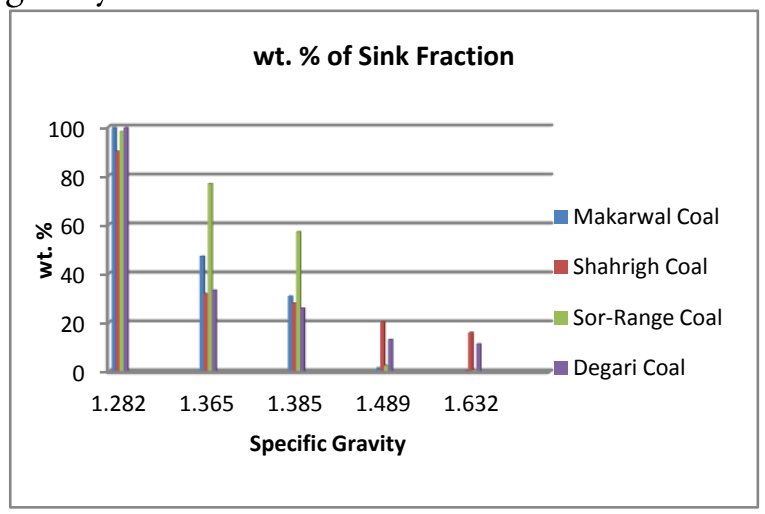

Fig.17. Weight Percentage of Sink Fractions in Different Coal Samples at Different Specific Gravities

Figure 18 shows percentage of ash in the sink fractions of the four coal samples at different specific gravities. The increase in ash percentage with increase in specific gravity is quite significant in case of Sharigh and Degari coals compared to the other two coal samples.

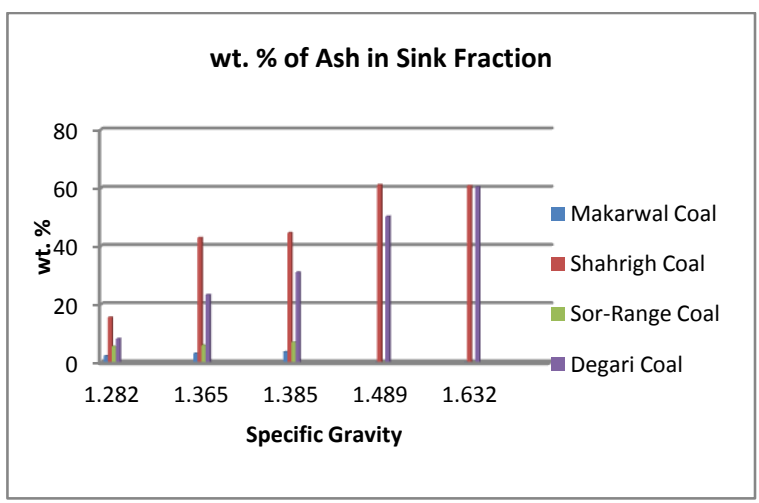

Fig.18. Weight Percentage of Ash in Sink Fractions in Different Coal Samples at Different Specific Gravities

As discussed earlier, high ash content in the sink fractions of these coals at the higher specific gravities indicate that significant part of the ash forming matter may be present in association to the inorganic matter in coal which can easily be separated in medium of high specific gravities.

Figure 19 shows the trace metal content in sink fractions of all the four coal samples at different specific gravities. The figure clearly shows that significant enrichment of trace metals has occurred in the sink fractions of 
Shahrigh and Degari coal samples with increase in specific gravity of the medium. Most of the trace metal contents are highest at the highest specific gravity 1.632. Previous studies based on float and sink analysis [1-18] indicates different degree of organic and inorganic association of various trace metals in case of different coals. An element having high organic association in one coal sample might have high inorganic association in another coal. Even though float and sink separation is generally being used for determining the organic and inorganic association of trace elements in coal, trace elements in the float fraction may not be indicative of their true organic association in the coal structure. Enrichment of trace element might also be due to the presence of fine grained mineral particles embedded in the organic coaly matrix which are carried in the float fraction due to the overall low specific gravity of the coal particles containing these fine sized mineral grains.

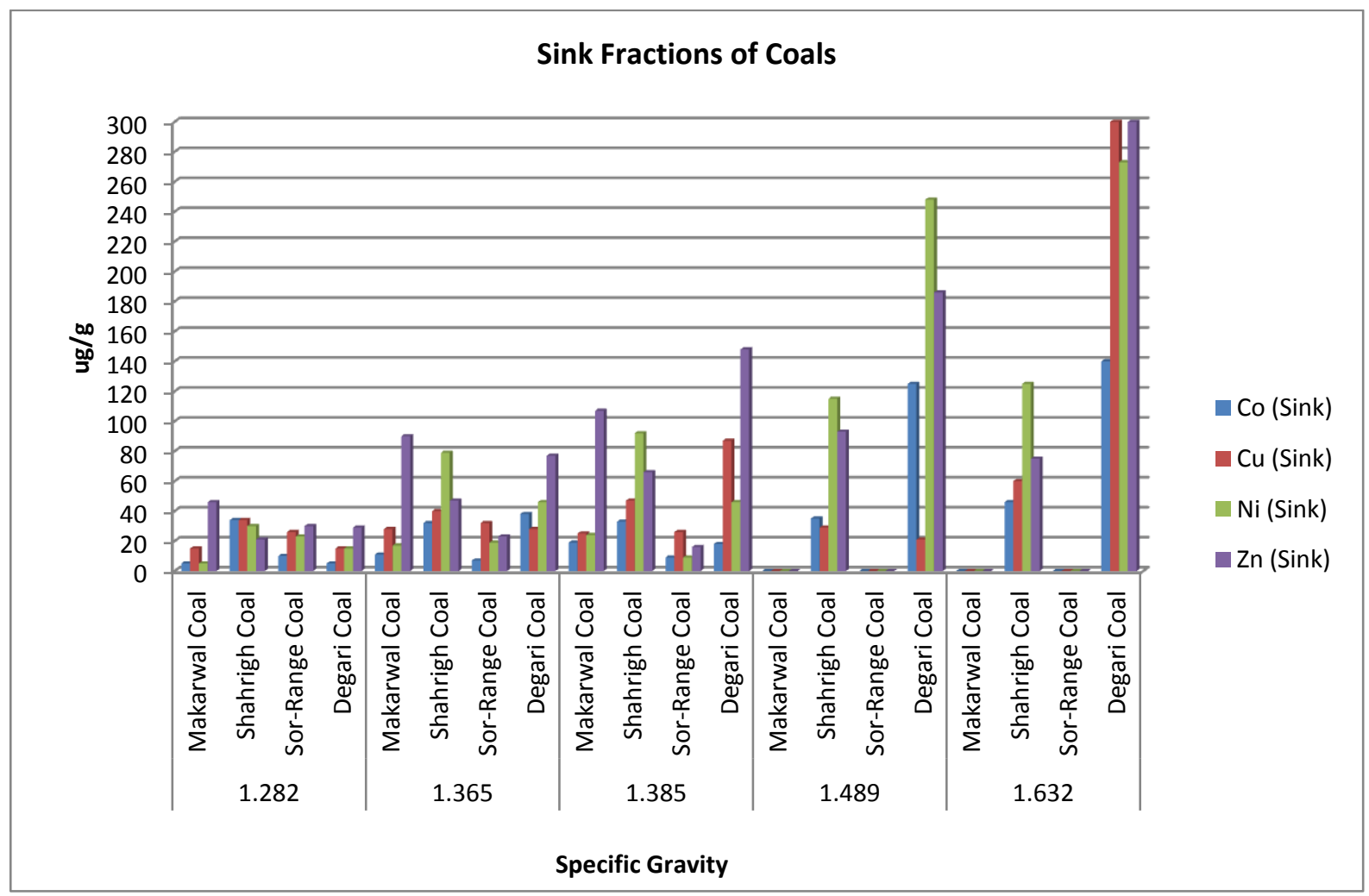

Fig.19. Concentration of Trace Elements in Sink Fractions of Coal Samples

\section{CONCLUSION}

Four Pakistani coal samples were separated in to float and sink fractions using media of different specific gravities. Trace elements Co, $\mathrm{Cu}, \mathrm{Ni}$ and $\mathrm{Zn}$ were determined in the whole coal and the various float and sink fractions. Following is a summary of our findings.
1. In Makarwal and Sore-Range coals, major part of $\mathrm{Co}, \mathrm{Cu}, \mathrm{Ni}$ and $\mathrm{Zn}$ may be present in close association to the organic coaly matter as ion-exchangeable ions, adsorbed species, organometallic complexes or as submicron size mineral particles embedded in the coal structure so intimately which are difficult to be separated by the float and sink method. 
2. In Shahrigh coal, $\mathrm{Zn}$ and $\mathrm{Ni}$ and in Degari coal, $\mathrm{Zn}$ and $\mathrm{Cu}$ may be present predominantly in inorganic forms which can easily be separated by float and sink method in medium of high specific gravity. Other trace metals in these coals might have variable association.

A detailed investigation is needed about the mode of occurrence of trace metals in these coals using modern instrumental techniques such as Instrumental Neutron Activation Analysis (INAA), Inductively Coupled Mass Spectrometry (ICP-MS) X-Ray Fluorescence (XRF), X-Ray Diffraction (XRD), and Scanning Transmission Electron Microscopy (STEM).

\section{ACKNOWLEDGEMENT}

The author is grateful to Mr.Kamran Usmani, secretary, Department of Chemical Engineering Technology and Mr Haider Ali, Department of Instructional Support Services, Yanbu Industrial College for their help in writing this manuscript.

\section{REFERENCES}

[1] Zheng, B., Ding, Z., Huang, R., Zhu, J., Yu, X., Wang, A., Zhou, D., Mao, D and Su, H, "Issues of Health and Disease Relating to Coal Use in Southwestern China", International Journal of Coal Geology, Vol. 40, 1999, pp.119-132.

[2] Gupta, D.C, “ Environmental Aspects of Selected Trace Elements Associated with Coal and Natural Water of Punch Valley Coalfield of India and Their Impacts on Human Health" International Journal of Coal Geology, Vol. 40, 1999, pp.133149.

[3] Tarrer, A.R., Guin, J.A., Outts, W.S., Gebket, J.P., Prather, H.W and Styles, G.A., Liquid Fuels from Coal (R.T. Ellington ed), Academic Press, 1977.

[4] Vejahati, F., Xu, Z., Gupta, R. "Trace Elements in Coal: Associations with Coal and Minerals and
Their Behavior during Coal Utilization-A Review”, Fuel, Vol. 89, 2010, pp.904-911.

[5] Mukhopadhyay, P.K., Goodarzi, F., Crandlemire, A.L., Gillis, K.S., MacNeil, D.J and Smith W.D., "Comparison of Coal Composition and Elemental Distribution in Selected Seams of the Sydney and Stellarton Basins, Nova Scotia, Eastern Canada”, International Journal of Coal Geology, Vol. 37, 1998, pp. 113-141.

[6] Dai, S., Ren, D., Chou, C., Finkelman, R.B., Seredin,V.V. and Zhou,Y., "Geochemistry of Trace Elements in Chinese Coal: A Review of Abundances, Genetic Types, Impacts on Human Health, and Industrial Utilization", International Journal of Coal Geology, 2011(In Press).

[7] Ketris, M.P., Yudovich, Y.E., "Estimations of Clarkes for Carbonaceous Biolithes: Word Average for Trace Element Contents in Black Shales and Coals", International Journal of Coal Geology, Vol. 78, 2009, pp. 135-148.

[8] Baruah, M.K., Kotoky, P., Borah, G.C., "Distribution and Nature of Organic/Mineral Bound Elements in Assam Coals India”, Fuel, Vol. 82, 2003, pp. 1783-1791.

[9] Zubovic, P. "Physicochemical Properties of Certain Minor Elements as Controlling Factors of Their Distribution in Coal", Adv. Chem. Ser., Vol. 55, 1966, pp. 221 -26.

[10] Gluskoter, H.J., "Mineral Matter and Trace Elements in Coal", in Trace Elements in Fuel (Babu S.P. ed), American Chemical Society, Advances in Chemistry, Vol. 141, , 1975, pp.1- 22.

[11] Swaine, D.J., "The Organic Association of Elements in Coals", Organic Geochemistry, Vol.18(3) , 1992, pp. 259-261.

[12] C. Ward, "Mode of Occurrence of Trace Elements in Some Austrian Coals" Coal Geol. Vol.2(77), 1980.

[13] Martinez-Tarazona, M.R., Spears D.A., and Tascon, J.M.D., "Organic Affinity of Trace Elements in Austrian Bituminous Coals", Fuel, Vol.71, 1992, pp.909-917.

[14] Preis, L.L., Fabiańska , M.J., Ćmiel, S., Kita, A.,"Geochemical Distribution of Trace elements in Kaffioyra and Longyearbyen Coals, Spitsbergen, Norway", International Journal of Geology, Vol.80, , 2009pp.211-223.

[15] Huggins, F.E., Seidu, L.B.A, Shah, N., Huffman, G.P., Honaker, R.Q., Kyger, J.R., Higgins, B.L., Roberston, J.D., Pal, S., Seehra, M.S., "Elemental 
Modes of Occurrence in an Illinois \# 6 Coal and Fractions Prepared by Physical Separation Techniques at a Coal Preparation Plant", International Journal of Geology, Vol.78, 2009, pp.65-76.

[16] Khan M.A., Ahmad I., Tariq Jan, M. and Karim, I, "Mineral Matter Identification in Some Pakistani Coals" Fuel Processing Technology, Vol.75, 2002, pp.1-8.

[17] Ahmad, I., Khan,M.A., Shakiullah, M. and Ishaq, M., "Vat Leaching of Bulk Mineral Matter from Some Pakistani Coals-Effect of Leachant Concentration", J.Chem.Soc.Pak, Vol.25(4) , 2003, pp.289-295.

[18] Shakirullah, M., Ahmad, I., Khan, M.A., Ishaq, M., Rehman, H. and Khan, U," Leaching of Minerals in Degari Coal”, Journal of Minerals and Materials Characterization and Engineering, Vol.5 (2) , 2006, pp.131-142.

[19] Khan, M.A., "Washabilty Study of Four Pakistani Coals by Float and Sink Technique-I", J. Chem. Soc. Pak., Vol.11 (3) , 1989, pp.242-245. 


\title{
دراسة خاصية الفصل بالغسيل لأربع عينات فحم من مناطق مختلفة في الباكستان بإستخدام تقتية التعويم للحصول على

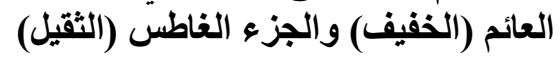

\author{
محمد أرسلا خان \\ قسم تقنية الهندسة الكيميائية، كلية ينبع الصناعية، المملكة العربية السعودية
}

الملخص:

هذه الدراسة أجريت على عينات من الفحم من مناطق مختلفة في الباكستان حيث نم فصلها إلى جزئين، جزء خفيف عائم وجزء ثقيل غاطس، بإستخدام مواد تعوييم ذات كثافة نوعية مختلفة ـ بعد حرق عينات الفحم و الأجزاء الناتجة عن عمليات التعويم (الخفيف والثقيل) في فرن حراري على درجة 750م للحصول على الرماد و الذي نم تحليله بطريقة الإمتصاص الذري الطيفي لتحديد نسب الكوبالت و النحاس و النيكل و الزنك قبل وبعد عملية التعويم . لقد بينت النتائج أن تراكيز هذه المعادن كانت قليلة في الجزء الثقيل في عينات الفحم من مناطق ماكروال وسورينج ولكن وجد أن تر اكيز المعادن أعلى في الجزء الثقيل لعينات الفحم التي تم أخذها من مناطق ديغاري وشاهري ـ لقد تم شرح النتائج بالإعتماد على درجة إرتباط هذه المعادن بالمو اد العضوية الموجودة في الفحم حيث عزي تناقص هذه المعادن في الجزء الثقيل للعينات المأخوذه من ماكارو ال وسورينج إلى قوة إرتباط هذه المعادن بالبناء العضوي للفحم مما يؤدي إلى صعوبة فصلها بطرق التعويم العادية. وفي حالة عينات الفحم من مناطق ديغاري وشاهري فمن المكن أن تكون المعادن لها رابطة ضعيفة في مركبات الفحم العضوية بحيث يسهل فصلها بطرق التعويم الرغوي. 